REPORTS OF MORPHOLOGY
$\begin{gathered}\text { Official Journal of the Scientific Society of Anatomists, } \\ \text { Histologists, Embryologists and Topographic Anatomists } \\ \text { of Ukraine } \\ \text { journal homepage: https://morphology-journal.com }\end{gathered}$

\title{
Possibility of the treatment effects on the dynamics of apoptosis processes in tissues of kidneys in acute pyleonephritis and comparative diabetes mellitus in the experiment
}

Borisov S.O. Kostev F.I., Borisov O.V., Molchaniuk N.I.

Odessa National Medical University, Department of Urology and Nephrology, Odessa, Ukraine

\section{ARTICLE INFO}

Received: 12 March, 2018

Accepted: 30 April, 2018

UDC: 616.61-002.16-092:616.397-

008.64

\section{CORRESPONDING AUTHOR}

e-mail: borisov-urol@ukr.net Borysov S.O.

\begin{abstract}
Programmed cell death under conditions of an infectious-inflammatory process plays a biologically exclusively positive role in the elimination of cells. Acute inflammatory process is a phenomenon capable of excessive concentration of aggressive effectors of inflammation. The aim of the work was to assess the dynamics of ultrastructural changes and early signs of apoptosis in the kidney tissues in experimental modeling of acute pyelonephritis $(A P)$ and concomitant diabetes mellitus (DM) of type II and II when conducting complex drug correction. The work was performed on 300 adult Wistar rats, divided into 6 groups. Fragments of the kidneys were studied and photographed in the electron microscope PEM100-01. In the kidneys of animals of the group, where traditional medical correction was used after the friendly modeling of pyelonephritis and type I diabetes, it was found that the glomerular ultrastructure was more preserved, but part of the capillaries of the glomerulus remained deformed with a narrowed lumen, there are signs of insufficient restoration of the glomerular capillary network. In the group of animals using the proposed complex drug correction, the renal structure was preserved, the capillaries of the glomerular network with unchanged architectonics. It has been established that the traditional medical correction did not sufficiently contribute to the restoration of damaged kidney tissue ultrastructure. After carrying out the complex medical correction proposed by us after a friendly simulation of an OP of DM type II, the ultrastructure of the kidney tissue in form and structure approached that of control animals, signs of a compensatory-restorative process appeared: most of the podocytes were hyperplastic and hypertrophied. The podocytes of the outer leaflet were in the active phase of activity, as evidenced by an increase in contractile function and, possibly, the release of urine from the cavity into the lumen of the proximal tubules. The structure of the tubules and interstitial tissue is close to the structure of the group of control animals, only in the cytoplasm of the podocytes of the proximal tubules there is an increased content of lysosomes. The ultrastructure of the glomeruli was normalized; the number of hypertrophic podocytes of the inner leaflet with signs of enhanced protein synthesis increased. Changes in the structures of the cortical and medulla are similar except for the state of cytotrabeculae, where their size decreased in the medulla and signs of deformation of the plasmolemma appeared. In experimental modeling of PD and DM of types I and II, pronounced ultrastructural changes in the kidney tissues were established, and manifestations of early apoptosis processes are significantly limited. The use of the complex drug correction proposed by us stimulates the development of the reparative processes of the kidney and moderately activates apoptosis. The addition of multi-vector preparations (Armadin and Nuklex) to the complex of treatment intensifies compensatory-restorative changes in the kidneys and apoptosis, which contributes to the elimination from the renal microstructures of excess damaged cells and aggressive effectors of inflammation.

Keywords: kidneys, ultrastructure, acute inflammation, hypertrophy, medication correction, apoptosis, modeling.
\end{abstract}

\section{Introduction}

Studies of recent years have shown that programmable cell death (PCD) in conditions of a variety of pathological

conditions, which includes the infectious and inflammatory process, can probably play a biologically positive role in 
the elimination of cells, the persistence of which has a pronounced negative effect on the organ and system organs $[11,19,22,23,24,26,27,28,31]$. With regard to the acute infectious-inflammatory process, the above-mentioned phenomenon is capable of effectively eliminating the excessive accumulation of aggressive inflammatory effector, which provides a favorable course of the disease $[1,12,13$, $15,16,19,27,28]$.

In studies of authors Vinnichenko L. N. (1980) and Verlander J. W. (1998) [27, 28], it has been established that kidney diseases are accompanied by a number of specific features of programmed cell death (PCD). Thus, inhibition of apoptosis is observed with most different morphological variants of glomerulopathy.

At the same time, obstructive nephropathy, reflux nephropathy, hydronephrosis, polycystitis, interstitial nephritis, and others are accompanied by its activation, reported by a number of researchers [1, 13, 14, 18]. It is known that in kidneys of a healthy adult, up to $3.0 \%$ of glomerular cells are daily exposed to apoptosis [13, 15, 20]. There are studies of a number of authors devoted to the study of the deep mechanisms of the apoptotic process and its major effectors $[7,10,20,24]$. Separately, the so-called "mitochondrial pathway of apoptosis" is isolated, which is carried out by indirect neutralization of anti-apoptotic effects at the cellular level [1, 2, 7, 10, 25, 27]. It has been established that factors that alter oxidative-reducing homeostasis in cells, such as hypoxia and oxidative stress, can stimulate the expression of regular apoptosis modulators both in vitro and in vivo $[6,8,9,18,21,24,29,30]$. The process of apoptosis in a different kidney disease today is not sufficiently studied. Modern drugs can influence the processes of apoptosis and, in some way, correct the ultrastructural changes of the kidneys, which require further research.

Taking into account the data obtained by us that electron microscopic studies are highly informative in the study of pathological changes and early dynamic processes of apoptosis in kidney tissues, the aim of the work was to: assess the dynamics of ultrastructural changes and early processes of apoptosis in renal tissues in the experimental modeling of acute pyelonephritis and concomitant diabetes mellitus type I and II under conditions of complex drug correction.

\section{Materials and methods}

The work was performed on 300 adult Wistar rats, divided into 6 groups: group A - control (30 intact animals); group B (35 animals, acute pyelonephritis modeling); group $E$ (50 animals, simulation of acute pyelonephritis and type I diabetes with traditional treatment); group $F$ (50 animals with simulation of acute pyelonephritis and type 1 diabetes mellitus in the complex treatment offered by us), group $G$ (50 animals with simulation of acute pyelonephritis and type II diabetes with traditional treatment), group $\mathrm{H}$ (50 animals with simulation of acute pyelonephritis and diabetes mellitus II type with the complex treatment offered by us).
The collection of material for electron microscopic research was carried out in an experiment conducted by the authors Borysov S. O. with co-authors [4]. The ultra-thin sections obtained in the experimental work were contrasted by Reynolds E.S. [22]. The work was carried out in the laboratory of pathoanatomical and electron microscopic research.

In the traditional medication correction in a group of animals with diabetes and pyelonephritis, an intramuscular injection of antibiotic. "Hepacef" injected at a dose of $30 \mathrm{mg}$ per kg body weight 2 times a day for 14 days after the simulation of acute pyelonephritis. With the proposed comprehensive medical correction after the simulation of acute pyelonephritis and diabetes mellitus, in addition to the antibiotic "Hepacef" in the above scheme, received the drug "Nuklex" per os at the rate of $1 \mathrm{~kg}$ of weight $7 \mathrm{mg} 3$ times a day and intramuscular injection of preparation "Armadin" by $1.5 \mathrm{mg}$ per $1 \mathrm{~kg}$ of weight 3 times a day for 14 days.

\section{Results}

In our previous study, the ultrastructure of the renal cortex and renal medulla material of the kidney of animals of the control group (A) was studied and described [4].

An electron microscopic study is performed on the kidneys of animals of group E (models of AP and DM type I with the use of traditional drug correction). While studying the renal cortex, it was found that the capillaries in the glomeruli have a focal length of the enlarged lumen, in which its content of elevated electron density is located. Endothelial cells of capillaries, mainly with unchanged ultrastructure. However, some of them differed in the clarified cytoplasm and the dilute arrangement of their organelles, clearly identified fenestri (Fig. 1).

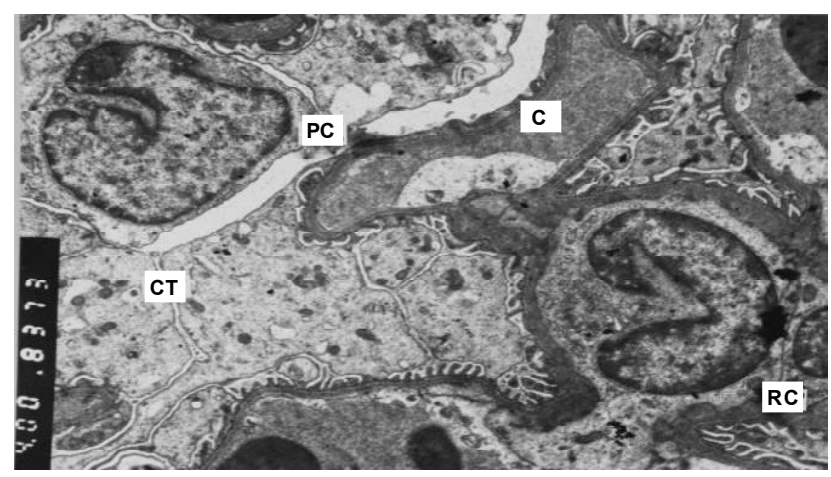

Fig. 1. Ultrastructure of rat renal cortex (group E). Traditional drug effect. Signs of edema of the cytoplasm of the endothelial cells of the capillaries and the expansion of the elements of the granular endoplasmic net in the cytotrebeculae of the glomerular capillary net. Electronic Microphotography. x4000. Here and thereafter: RC - renal cortex, C - capillary, CEC - capillary endothelial cell, CT - cytotrebecula, $\mathrm{CP}$ - cytopodia, CV - cavernous vesicles, CF - collagen fibrils, PC podocyte, $\mathrm{N}$ - nucleus, $\mathrm{M}$ - mitochondria; RM - renal medulla, MC mesangiocyte, E - erythrocyte, GER - granulated endoplasmic reticulum, IT - interstitial tissue, RPT - renal proximal tubules, BM - basement membrane, GCN - glomerular capillary network. 
Basement membrane has increased tortuosity. The cavity of the capsule is significantly narrowed in places, in this section cytopedicules are single, short and thickened, cytotrabeculaes are short and have a slightly electron-dense cytoplasm. In cavity we can see a substance identical to that of the capillary lumen.

In other areas, cytopodies and cytotrabeculaes have a structure close to normal. Podocytes are characterized by large cell sizes, large nuclei and shallow folds of karyolemma. There are nucleolus in the karyoplasm. The cytoplasm has well expressed polysomes and mitochondria. In the podocytes of the proximal tubules, the ultrastructure is close to normal, only in some cells there is a decrease in the number of mitochondria and enlightenment of the cytoplasmic matrix. In the podocytes of the distal tubules, the devastated areas of the cytoplasm are marked centrally. Enlightenment of the main substance is manifested in interstition of the connective tissue. As for the electron microscopic picture of the renal medulla of the group $E$ animals, we found that the capillary net of the glomeruli was well expressed. It was established that the gaps of the capillaries were extended compared to the control group material, and the area of the cavity was slightly narrowed. Enlarged electron density of lumen content. Endothelial cells of a number of capillaries with signs of hydropic changes, others have a structure close to the usual structure. The majority of podocytes of the inner layer was found to have an unmodified ultrastructure, only in some of them, expanded tanks of the granular endoplasmic grid were installed. Cytopodies are thickened in some places (Fig. 2).

In the proximal tubules, the part of the podocytes has a reduced number of mitochondria, and those in the cell are manifested with the pathology of mitochondrial and cytoplasmic basical structures, others with an increased number of mitochondria in the cells. In all cells, the number of vacuoles is reduced. In the part of the podocytes of the distal tubules there are signs of edema of the cytoplasm and the destruction of part of the organelles with a focal destruction of the basal strain. Interstitial tissue sites are determined by the clarification of its main substance. Thus, the structure of the nephron after the traditional treatment ultrastructure is more conserved than in the group with the simulation of acute pyelonephritis. To a greater extent expressed large hypertrophied, with active nuclei of podocytes, different sizes of cytotrebeculaes, there was a large number of cytopedicules. Only certain cytotrabeculae are slightly deformed, noticeably compressed. In the cavity of the capsule appear freely located separate rounded forms of the cytotrabeculaes. Capillaries have the shape and arrangement similar in structure of the control group of animals. They differ only in the more dense content of their lumen and the presence of part of the endothelial cells with signs of hydropic changes.

In a similar electron microscopic study, the kidneys of animals of group F (model of AP and I type of diabetes and with proposed complex of medical correction - with the use

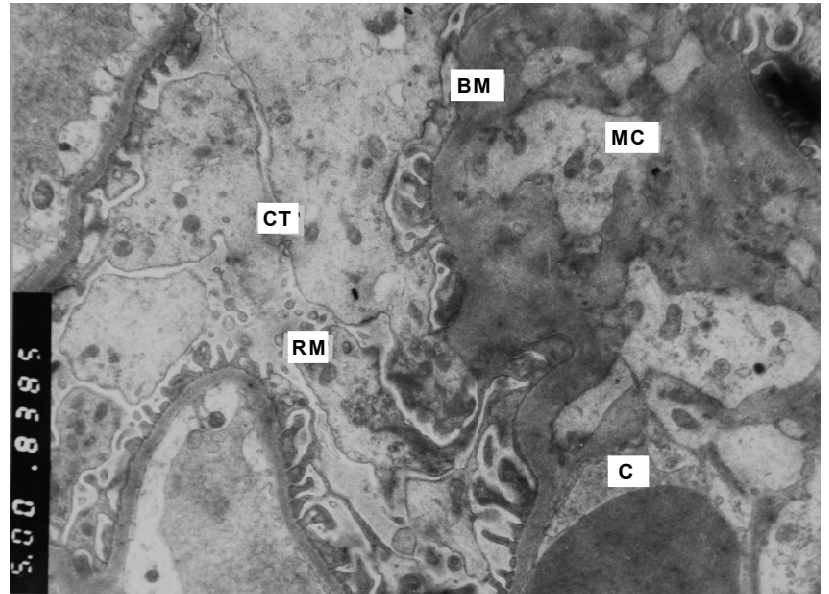

Fig. 2. Ultrastructure of rat renal medulla (group E). Traditional drug effect. Signs of edema of the cytoplasm of the endothelial cells of the capillaries, the processes of mesangial cells are well expressed. EMP. $x 5000$.

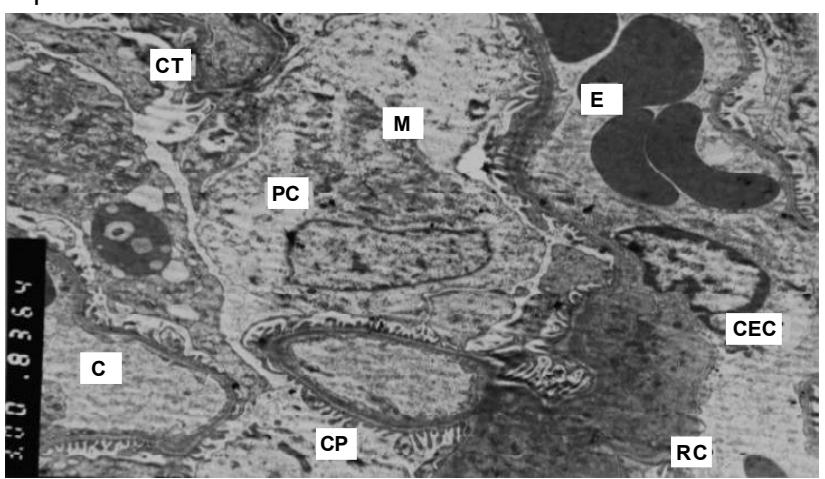

Fig. 3. Ultrastructure of rat renal cortex (group F). Proposed pharmacological effect. Hypertrophic podocytes with expanded elements of the granular endoplasmic net. EMP. x3000.

of preparations of multi-vector action of Armadin and Nuklex). In studying the renal cortex of animals, it was discovered that the ultrastructure of the glomerular capillaries is close to that of the control animals. Attention is drawn to somewhat extended areas of the contents of mesangial tissue. The capillaries in the cross section are round or close to the oval shape. Enlargement of capillaries of regular diameter with content of moderate density. There are isolated red blood cells in it. Endothelial cells in the majority are unchanged, but there are isolated cells with signs of edema (Fig. 3).

In a well-defined cavity there are large podocytes and cytotrabeculaes with a large number of their intracellular organelles, as well as individual cell fragments and bubbles of various sizes. As for the electron microscopic picture of the renal medulla of animals, it was found that in the renal glomeruli the podocytes of the outer layer in the majority with the unchanged structure. Some podocytes are in a state of increased metabolic activity. The glomerular net capillaries do not differ much from such a control group, but their part has a slightly narrowed lumen. Endothelial cells with signs of edema are found on thinned areas of the cytoplasm. Fenestra also well-defined in this area. The brightness of 


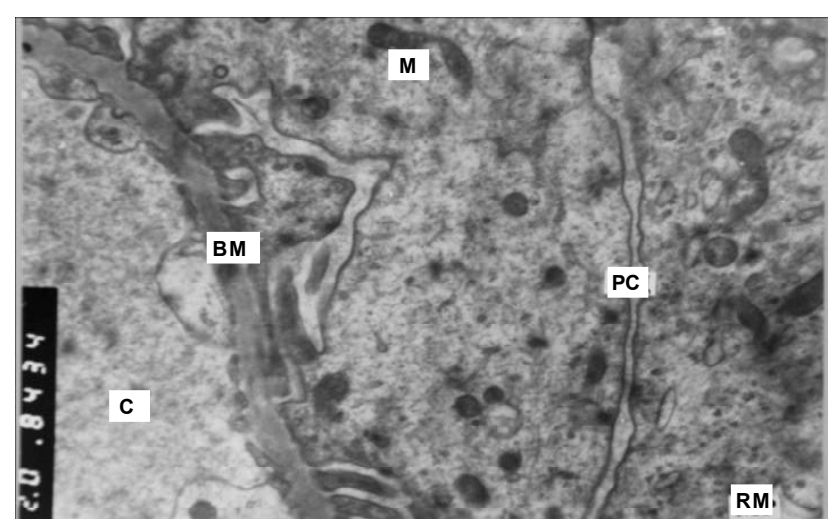

Fig. 4. Ultrastructure of rat renal cortex (group F). Proposed pharmacological correction. In the cavity of the capsule, fragments of hypertrophied cytotrabeculaes are observed. EMP. x6000.

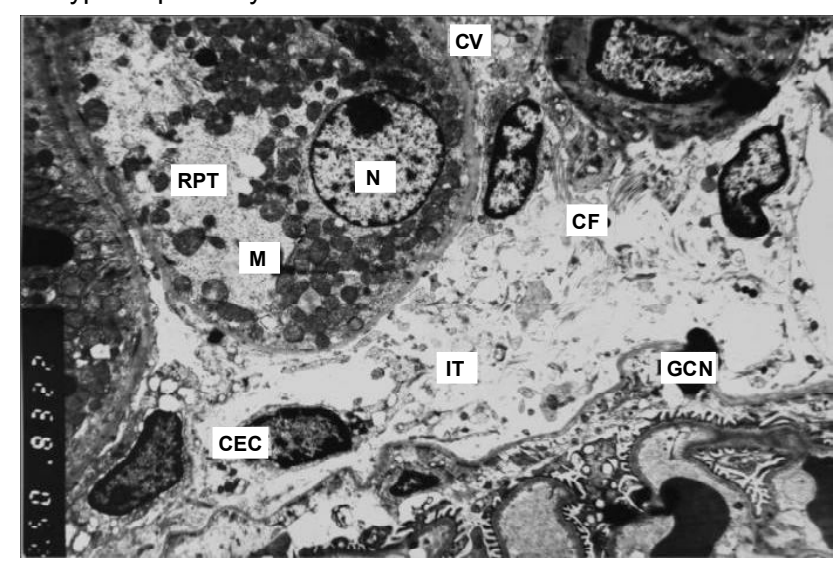

Fig. 5. Ultrastructure of rat renal cortex (group G). Traditional drug correction. Structures of interstitial tissue with signs of edema. Electronic microphotography. $\times 2500$.

some capillaries is filled with moderate density, others are more electronically dense. It contains single red blood cells or large electron-transparent vacuoles. Mesangiocytes that come in contact with capillaries are well-defined.

The cavity of the capsule is filled with a large number of large cytotrabeculae of the inner layer, which has a normal structure and is in contact with both the cytopedicules and with each other. The cytopepidicles throughout the basal membrane are well expressed. In the cytoplasm of the part of cytotrabeculaes, the expansion of the elements of the granular endoplasmic net and the edema of the intramitochondrial matrix with the focal destruction of the crust, which is possibly a sign of apoptosis in these cells, is noted. Locally there are podocytes of large size with a large nucleus and with an increased number of intracellular organelles, which indicates an increase in their functional activity (Fig. 4).

Ultrastructure of proximal tubules practically unchanged. Only in separate proximal tubules there are single vacuoles and lysosomes. Interstitial tissue draws attention to the increased number of cells. Ultrastructure of the distal tubules without visible structural changes.

At the same time, we carried out an electron microscopic study of the kidneys of animals of the G group (model of AP and type II diabetes with the use of traditional drug correction). During the study of the renal cortex of animals, it was found that in the renal glomeruli the outer layer of the capsule led on the basal membrane, its podocytes had an electron-enlightened cytoplasm. The cytoplasm has well expressed polysomes and mitochondria. Detected close contacts between adjacent podocytes. In the increased in volume nuclei there is a margin of chromatin and in the central zone of the nucleus, chromatin predominates in a diffuse state. The glomerular capillaries have winding contours. Enlargement in most of the capillaries is narrowed and has an elevated electron density. It contains slightly deformed erythrocytes. Endothelial cells, in general, had signs of edema and destruction of the main part of the organelles. However, part of bodies of endothelial cells in structure is close to the same control group of animals. The space of the capsule was narrowed. It should be noted that the number of podocytes and cytotrabeculaes is reduced, their area is also significantly reduced. They look wrinkled, their cytoplasm is winding (Fig. 5).

Most of the podocytes and cytotrabeculaes are in a state of destruction, in which gelization of cytoplasm is observed. Cytopodiesare absent somewhere. In general, they have an increased density of the cytoplasm, somewhat deformed, their structure differs indistinct, which should be considered an expression of apoptosis. The number of podocytes and cytotrabeculaes in the glomerular is reduced, in the greater part of the cytoplasm has an electron-dense appearance, and its organelles are in a state of edema. Some podocytes and their processes are almost unchanged. In proximal tubules, the podocytes are in a different state: part of their usual unchanged structure, and part with signs of alteration. In such podocytes the cytoplasm is enlightened, that is, with signs of edema, especially apical part of it. In the podocytes of the distal tubules, there are also marked signs of edema of the apical area cytoplasm and a decrease in the number of organelles. It encounters a large number of vacuoles and mitochondria, which are pathologically altered (Fig. 5). In interstition focal signs of edema of the main substance and intracellular organelles of capillaries appear.

During the study of the renal medulla of animals, it was found that the glomerular capillaries have slightly winding contours. Endothelial cells have signs of cytoplasmic edema. Other endothelial cells encountered a reduced number of organelles, expanded in the subtle parts of the cytoplasm. Some endothelial cells contained signs of activation of the cytoplasmic structures. The content of the lumen of capillaries of moderately elevated electron density. Podocytes and cytotrabeculaes of large size, densely filling the cavity of the capsule. They were with a slightly enlightened cytoplasm. Cytoplasm is regularly located along the basement membrane. Somewhere they have an electrondense cytoplasm. Some cytotrabeculaes with deep degenerative changes (Fig. 6). They are located between the podocytes with unchanged ultrastructure. In proximal 
and distal tubules, there are podocytes with unchanged structure and with signs of pathological changes in mitochondria and slightly enlightened cytoplasm. In the podocytes of the proximal tubules there are different sizes of lysosomes, which indicates the increased need for cells to dispose of its damaged elements. In the interstices there are manifestations of minor edema of the main substance and the cytoplasm of the endothelial cells of the microvessels that are located there.

Based on the results of the electron microscopic picture, it can be thought that the traditional treatment did not sufficiently contribute to the restoration of damaged ultrastructure of the renal tissues.

In accordance with the tasks of the study, electron microscopic study was carried out on the kidneys of animals of the group $\mathrm{H}$ (modeling of AP and type II diabetes in the complex treatment offered by us with the use of drugs of multi-vector action - Armadin and Nuklex).

In the study of the renal cortex of animals, it was determined that in the glomeruli the podocytes of the outer layer have an enlarged nuclei and a cytoplasm relative to the control group material. The inner layer is characterized by the fact that the cytopodies are present throughout the basement membrane, and in places they are thickened. From some cytopodies, quite large cytotrabeculaes branch out. These cells have moderately electron-dense cytoplasm, in which markedly increased number of organelles. In addition, in the capsule space there are rather large podocytes in the state of hyperplasia and hypertrophy. They contain a large nucleus and organelles enriched in the cytoplasm. The nucleus has a convoluted karyolemma and its separate invaginations, which increases the surface area of the nucleus and metabolic processes with the cytoplasm. Nuclear chromatin is in a diffuse state. The condition of capillaries is practically no different from that of control animals. A smaller density of contents in the lumen of capillaries, close to such control animals was noted (Fig. 7).

Podocytes of PT and DT by their structure do not differ from such control material, there is a somewhat increased amount of lysosomes in podocytes of PT. Interstitial tissue has places slightly enlightened amorphous connective tissue substance and a large number of its large cells with large nuclei.

In electron microscopic study of the renal medulla found that the ultrastructure of the renal glomerulus is well expressed. Podocytes of the outer layer have (like in the renal cortex) increased nucleus and cytoplasm compared with the control group. In the nucleus, chromatin diffuse state predominates, and in the cytoplasm an increased number of polysomes, elements of the granular endoplasmic net, mitochondria, and Golgi complex. Most of the glomeruli capillaries in the lumbar cut have correct round or oval shape. Enlightenment of capillaries is slightly extended with moderate electron density. Endothelial cells of capillaries have an ordinary structure with clear fenestra. Cytopodies

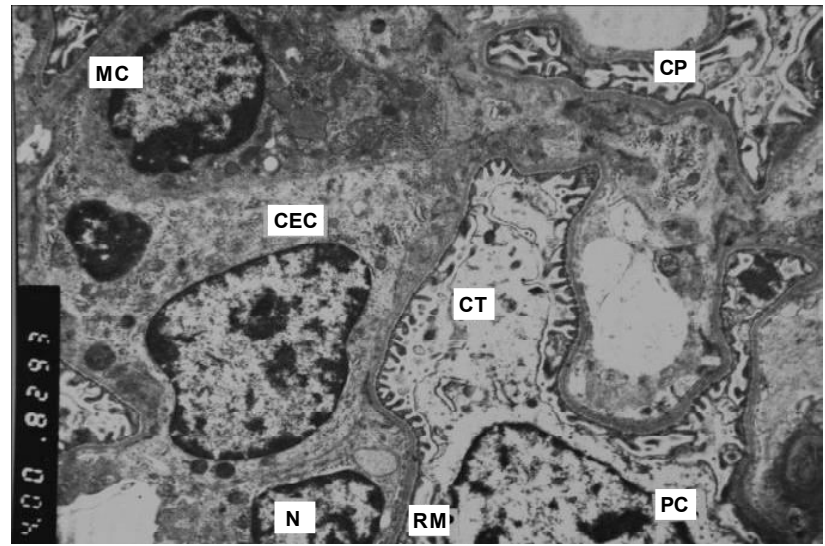

Fig. 6. Ultrastructure of rat renal medulla (group G). Traditional drug correction. The cavity of the capsule is slit-shaped. Hypertrophy of capillary endothelial cell, focal destruction of the cytopedicules. Hydrophobic changes in the podocytes and cytotrabeculaes of the glomerular capillary network. Electronic microphotography. $x 4000$.

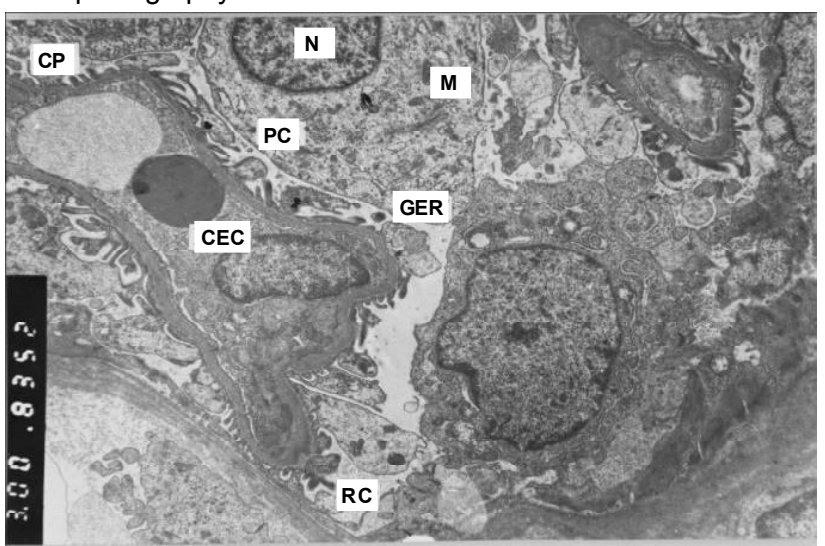

Fig. 7. Ultrastructure of rat renal cortex (group H) after the proposed drug correction. The structure of the glomerular capillary network with elements of activation of intracellular metabolic processes, both in the podocytes, and in the endothelial cells of the capillaries. Electronic microphotography. $\times 3000$.

are present throughout the length of the basement membrane. Well defined cytotrabeculaes. Some of them have an increased number of intracellular structures. Part of the mitochondria is in the state of cellular degeneration, which may be due to the increased energy requirement for intracellular metabolic processes. Granular endoplasmic network tanks are expanded, which may be a manifestation of the onset of apoptosis in cells (Fig. 8).

In addition, part of the podocytes has a large size, an elevated electron density cytoplasm, in which extended elements of the granular endoplasmic net and edema of the mitochondria are observed, which is also probably due to the manifestations of apoptosis in these cells. Some of the large cytotrabeculaes have a much narrower cytoplasm, almost in the form of a filiform leg. Separate cytotrabeculaes are interconnected with the same narrow processes. Mesangial cells have unchanged structure, in some of them in the cytoplasm there are two nuclei, or the nuclei have 


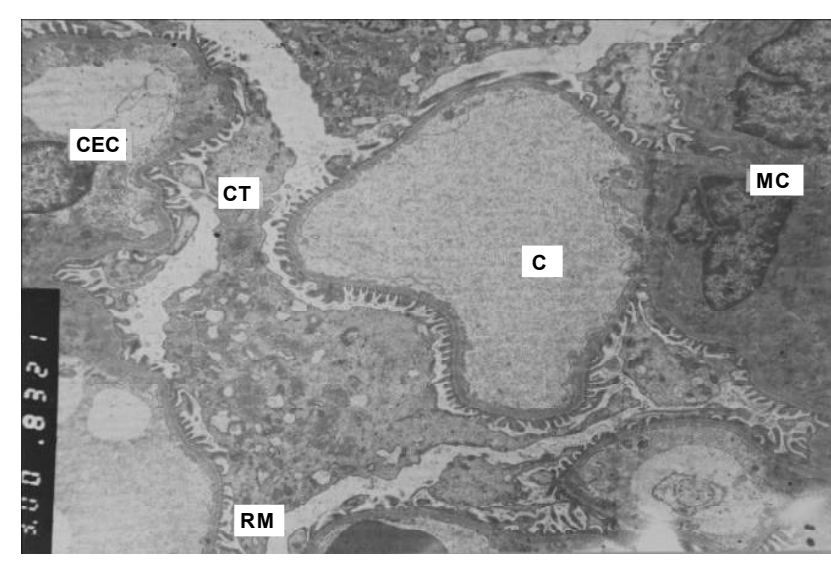

Fig. 8. Ultrastructure of the rat renal medulla (group $\mathrm{H}$ ) after the proposed medication correction. Podocyte of the inner leaf and cytotrabeculaes with the extended elements of the granular endoplasmic net and the signs of mitochondrial edema. Electronic microphotography. $\times 3000$.

deep folds of karyolemma.

The proximal and distal tubules are unchanged, they show well mitochondria, nuclei in the active state, as evidenced by the chromatin, which is in a diffuse state. Wellformed basal and apical areas of their cells. In the area of interstitial tissue local signs of minor edema of the main substance are detected. Cellular and fibrous elements of connective tissue and amorphous substance without visible structural changes.

\section{Discussion}

Taking into account the data obtained, it should be noted that in the kidney of the animal group were we used traditional drug correction after the common modeling of pyelonephritis and type I diabetes, it was found that the ultrastructure of the glomerulus is more conserved than in the group without treatment. The cavity of the capsule is more pronounced, but the part of the capillaries of the glomerulus remains deformed and with a narrowed lumen. Among the podocytes and cytotrabeculaes with normal ultrastructure, there are often those with signs of degenerative changes of varying degrees of manifestation, indicating that the normal functioning of the glomerular capillary net has not been restored, which ensures the formation of primary urine and its filtration by the structures of the tubules. These data supplement and improve the researches of 2011-2014 [11, $12,17]$.

The use of traditional medication effects promotes the development of reparative processes in the kidneys and moderately activates apoptosis, proved in a number of works $[2,3,4,5,31]$.

The analysis of the ultrastructure of the nephron and tubules of rats in the group with the proposed comprehensive drug correction (with the use of preparations of multi-vector action of Armadin and Nuklex) and its comparison with the group with the traditional medication intervention showed that in the group of animals using our proposed comprehensive drug correction, the renal structure was more preserved. The capillaries of the glomerular mesh in most cases had an ordinary architectonics, endothelial cells were practically restored, fenestra differed well. The lumen of the capillaries has a high electron density. Podocytes of inner layer differs by polymorphic changes. Among the podocytes with normal structure there are cells with signs of their destruction and atrophy, as well as signs of their hypertrophy, indicating the activation of compensatory restoration processes. Separate fragments of cytotrabeculaes are freely located between the podocytes, which should be considered as an expression of apoptosis. Similar fragments are observed in the material of control animals, but in smaller quantities. It should be noted that the cavity of the capsule in this material is quite extensive.

As a result of the traditional treatment of animals after the common model of pyelonephritis with type II diabetes, the structure of the nephron is partially restored. Podocytes of the outer layer in the state of strengthening the proteinsynthetic and energy-forming function; in capillaries there is an edema of endothelial cells and an elevated electron density of its lumen. However, there are still signs of pathological changes in the part of capillaries and, in particular, their endothelial cells. Podocytes of inner layer in a greater number have an electron-dense cytoplasm and vacuolization of mitochondria, expanded granular endoplasmic mesh tanks. Mesangial tissue is more pronounced than that of control animals. Thus, in a significant part of the podocytes and cytotrabeculaes there is a rare disposition of cytopodies. The granular cluster is concentrated in the cavity, which confirms the violation of the barrier function and the smooth penetration of substances from the lumen of the capillaries to the cavity of the capsule of high molecular weight substances. In addition, in the cavity there are isolated pinocytosis bubbles. The revealed changes in the structure of the nephrons indicate that the function of the formation of primary urine is disturbed. At the same time, in parallel with the signs of alteration of the glomerular structures, the phenomena of compensatoryrestorative nature are determined, evidence of which is the restoration of the structure of some endothelial cells and their fenestra, individual podocytes. However, the gaps in capillaries have an elevated electron density. The structure of the tubules and interstitial tissue remain with the elements of hydropic changes. It should be noted that in the renal medulla, the ultrastructure of the kidney tissues is more conserved than renal cortex. It should be assumed that the traditional drug correction did not sufficiently contribute to the repair of damaged ultrastructure of the tissues of the kidney. Similar conclusions were made in the works of Bhayani S.B. with co-authors and Tirapelli L. F. with co-authors $[3,24]$.

After carrying out the complex medical correction proposed by us in the conditions of the common modeling of acute pyelonephritis and type II diabetes, the ultrastructure of the kidney tissues by form and structure is basically similar 
to that of control animals. Significantly, there are signs of a compensatory-restorative process of podocytes. Most of these cells are in a state of hyperplasia and hypertrophy, they are significantly enlarged in body size and explode into a well-defined cavity. Cell cytoplasm is filled with a large number of organelles, which confirms the enhancement of protein-synthetic, energy-forming and other cellular functions. Cytopodiaes and cytotrabeculaes are also enlarged, which greatly extends the filtration zone. Capillaries are slightly expanded, their lumen content does not differ from the similar structures of control animals. Podocytes with signs of alteration, as well as signs of their apoptosis, are found singly. Somewhere in the cavity there are fragments of cytotrabeculaes and signs of increased permeability of substances in the lumen of the cavity of the capsule. Podocytes of outer layer are also in the state of activating their activity, which reflects the increase of contractile function and, possibly, the release of urine from the cavity into the lumen of the PC. The structure of the tubules and interstitial tissue is close to the norm, only the cytoplasm of the PC podocytes shows an increased content of lysosomes, which reflects the active release of cells from their damaged elements.

Studies have shown that in the renal cortex ultrastructures after the proposed drug correction have the following characteristics: the ultrastructure of the glomeruli is close to normal; increased number of podocytes of the inner layer in a state of hypertrophy, in which signs of enhanced protein synthesis are manifested; EC of capillaries have a much higher restored structure compared to a group of animals receiving traditional treatment; in the cavity of the capsule there are cytotrabeculaes from which the fragments of the cytoplasm are trimmed, as well as their freely located fragments are observed; in the renal proximal tubules part of the podocytes with the local destruction of structures. It should be noted that changes in the structures studied in both the renal cortex and in the renal medulla are similar with the exception of the state of cytotrabeculae having signs of deformation of plasmolemma and reduction of size in the renal medulla.

Electron microscopic studies in pathological conditions,

\section{References}

[1] Bayrasheva, V. K. (2015). Modeling of diabetes mellitus and diabetic nephropathy in the experiment. Modern problems of science and education, 4, doi:10.17513/spno.127-21024

[2] Becker, F., Van Poppel, H., Hakenberg, O. W., Stief, C., Gill, I., Guazzoni. G. ... Stockle, M. (2009). Assessing the impact of ischaemia time during partial nephrectomy. Eur. Urol., 56, 625635.

[3] Bhayani, S. B., Rha, K. H., Pinto, P. A., Ong, A. M., Allaf, M. E., Trock, B. J. ... Kavoussi, L. R. (2004). Laparoscopic partial nephrectomy: effect of warm ischemia on serum creatinine. J. Urol., 172(4, Pt 1), 1264-1266.

[4] Borisov, S. O., Kostyev, F. I., Borisov, O. V., \& Molchanyk, N. I. (2018). Electron microscopic diagnostics of apoptosis processes under simulation conditions in the experiment of acute pyelonephritis and concomitant diabetes mellitus type I and II. Reports of Morphology, 24(1), 39-46. doi:10.31393/ which were modeled in the experiment, allowed to qualitatively analyze the changes occurring in separate cells of the kidneys tissues in the dynamics of apoptosis. The method of electron microscopy provides an opportunity to obtain objective information about the degree of apoptosis in individual tissues and organs. This further increases the arsenal of methods for assessing cell membranepathological effects in the pathogenesis of the pathological conditions under study and their dynamics in the implementation of a comprehensive drug effect.

\section{Conclusions}

1. According to the data of electronic microscopy in the experimental modeling of acute pyelonephritis and concomitant diabetes I and II types with the use of traditional medical correction, ultrastructural changes in the tissues of the kidneys are pronounced: the renal structure is more stable, the capillaries of the glomerular net with unchanged architectonics, endothelial cells are practically restored and manifestations of early processes of apoptosis are extremely limited; between the podocytes, somewhere are freely located separate fragments of the cytotrabeculaes, which should be considered as apoptotic manifestation.

2. The use of integrated therapeutic measures leads to the tendency developing of reparative processes of renal ultrastructures and promotes moderate activation of apoptosis.

3. Adding to the complex of pathogenetically induced drug correction (preparations of multi-vector action of Armadin and Nuklex) provides significant intensification of compensatory and restorative changes in the tissues of the kidney (a cytoplasm filled with a large number of organelles, which is a sign of enhancement of proteinsynthetic and energy-forming cell function) and a marked increase in the processes of apoptosis, which causes elimination of the renal microstructures of the excess of damaged cells, and high content of lysosomes reflects the active release from cells their damaged elements and aggressive inflammatory effects (signs of cytoplasmic edema and destruction parts of organelles).

morphology-journal-2018-24(1)-07

[5] Cippa, P. E., Fehr, T., Gaspert, A., \& Georgi, A. (2014). Druginduced acute interstitial nephritis. Praxis, 103(15), 865-872. doi: 10.1024/1661-8157/a001733.

[6] Donohoe, J. F., Venkatachalam, M. A., Bernard, D. B. \& Levinsky, N. G. (1978). Tubular leakage and obstruction after renal ischemia: structural-functional correlations. Kidney Int., 13(3), 208-222.

[7] Dorogoj, A. P. (2007). Life expectancy, potential labor potential losses, and death in diabetes mellitus. International Endocrinology Journal, 3(9), 10-12.

[8] Devarajan, P. (2006). Update on mechanisms of ischemic acute kidney injury. J. Amer. Soc. Nephrol., 17, 1503-1520.

[9] Gill, I. S., Colombo, J. R. Jr., Moinzadeh, A., Finelli A., Ukimura O., Tucker K., \& Desai, M. (2006). Laparoscopic partial nephrectomy in solitary kidney. J. Urol., 175(2), 454-458. DOI: 
10.1016/S0022-5347(05)00150-3

[10] Habib, S. L. (2013). Diabetes and renal tubular cell apoptosis. World J. Diabetes, 4(2), 27-30. doi: [10.4239/wjd.v4.i2.27]

[11] Hansson, J., Hultenby, K., Cramnert, C., Pontén, F., Jansson, H., Lindgren, D. ... Johansson, M. E. (2014). Evidence for a morphologically distinct and functionally robust cell type in the proximal tubules of human kidney. Human Pathol., 45, 382-393.

[12] Humphreys, B. D., Czerniak, S., Dirocco, D. P., Hasnain, W., Cheema, R., \& Bonventre, J. V. (2011). Repair of injured proximal tubule does not involve specialized progenitors. Proc. Natl. Acad. Sci., 108(22), 9226-9231. doi: 10.1073/ pnas. 1100629108

[13] Korol, L., Stepanova, N., \& Migal, L. (2016). Practical value of determination of indicators of oxidative stress in patients with pyelonephritis. Ukrainian Journal of Nephrology and Dialysis, 52(4), 71-76.

[14] Krijnen, P. A. J., Simsek, S., \& Niesse, H. W. M. (2009). Apoptosis in diabetes. Apoptosis, 14(12), 1387-1388. doi: [10.1007/ s10495-009-0419-6]

[15] Kuznetsova, O. P., Vorobyov, P. A., \& Yakovlev, S. V. (1997) Urinary tract infections. Russian Medical Journal, 1, 4-13.

[16] Liu, X., Guan, Y., Xu, S., Li, Q., Sun, Y., Han, R., \& Jiang, C. (2016). Early Predictors of Acute Kidney Injury: A Narrative Review. Kidney Blood Press Res., 41(5) 680-700. DOI: 10.1159/000447937

[17] Manda, G., Checherita, A.-I., Comanescu, M. V., \& Hinescu, M. E. (2015). Redox signaling in diabetic nephropathy: hypertrophy versus death choices in mesangial cells and podocytes. Mediators of Inflammation, 2015, 13. Article ID 604208. http://dx.doi.org/10.1155/2015/604208

[18] Nagornaya, N. V., \& Chetverik, N. A. (2010). Oxidative stress: effects on the human body, assessment methods. Child Health, 23(2), 140-145.

[19] Novikov, V. S. (1996). Programmed cell death. S.-Pb.: Science.

[20] Pavlyuchenko, I. I. (2005). Oxidative stress, its monitoring and criteria for evaluating the antioxidant activity of drugs and dietary supplements. (dis. Doctor of Science). Kuban State Medical Academy, Peoples' Friendship University of Russia, Krasnodar.
[21] Porpiglia, F., Renard, J., Billia, M., Musso, F., Volpe, A, Burruni, R. ... Scarpa, R. M. (2007). Is renal warm ischemia over 30 minutes during laparoscopic partial nephrectomy possible? One-year results of a prospective study. Eur. Urol., 52(4), 1170-1178. DOI: 10.1016/j.eururo.2007.04.024

[22] Reynoldes, E. S. (1963). The use of lead citrate at higt $\mathrm{pH}$ an electron opaque stain in electron microscopy. J. of Cell Biol., $17,208-212$.

[23] Sancho-Martinez, S. M., Lopez-Novoa, J. M. \& LopezHernandez, F. J. (2015). Pathophysiological role of different tubular epithelial cell death modes in acute kidney injury. Clin. Kidney J., 8(5), 548-559. doi: [10.1093/ckj/sfv069]

[24] Tirapelli, L. F., Barione, D. F., Trazzi, B. F. M., Tirapelli, D. P. C., Novas, P. C., Silva, C. S. ... Martins, A. C. P. (2009). Comparison of two models for evaluation histopathology of experimental renal ischemia. Transplant. Proc., 41, 4083-4087.

[25] Thompson, R. H., Lane, B. R., Lohse, C. M., Leibovich, B. C., Fergany, A., Frank, I. ... Campbell, S. C. (2010). Every minute counts when the renal hilum is clamped during partial nephrectomy. Eur. Urol., 2010, 58(3), 340-345. doi: 10.1016/ j.eururo.2010.05.047

[26] Venkatesh, L., \& Hanumegowda, R. K. (2017). Acute Pyelonephritis - Correlation of Clinical Parameter with Radiological Imaging Abnormalities. J. Clin. Diagn. Res., 11(6), TC15-TC18. doi: [10.7860/JCDR/2017/27247.10033]

[27] Verlander, J. W. (1998). Normal ultrastructure of the kidney and lower urinary tract. Toxicol. Pathol., 26, 1-17.

[28] Vinnichenko, L. N. (1980). Comparative ultrastructure of nephron. J. Nauka, 136.

[29] Wangsiripaisan, A., Gengaro, P. E., Edelstein, C. L., \& Schrier, R. W. (2001). Role of polymeric Tamm-Horsfall protein in cast formation: Oligosaccharide and tubular fl uid ions. Kidney Int., 59, 932-940.

[30] Weinberg, J. M. (1991). The cell biology of ischemic renal injury. Kidney Int., 39, 476-500.

[31] Zhang, Y., Chen, X., Yang, L., Zu, Y., \& Lu, Q. (2015). Effects of rosmarinic acid on liver and kidney antioxidant enzymes, lipid peroxidation and tissue ultrastructure in aging mice. Food Funct., 6(3), 927-931. doi: 10.1039/c4fo01051e

\section{МОЖЛИВОСТІ ЛІКУВАЛЬНОГО ВПЛИВУ НА ДИНАМІКУ ПРОЦЕСІВ АПОПТОЗА В ТКАНИНАХ НИРОК ПРИ ГОСТРОМУ ПІЄЛОНЕФРИТІ ТА СУПУТНЬОМУ ЦУКРОВОМУ ДІАБЕТІ В ЕКСПЕРИМЕНТІ \\ Борисов С.О., Костев Ф.І., Борисов О.В., Молчанюк Н.І.}

Запрограмована клітинна загибель в умовах інфекційно-запального процесу відіграє біологічно виключно позитивну роль в елімінації клітин. Гострий запальний процес - це явище, здатне до надмірного зосередження агресивних ефекторів запалення. Метою роботи стала оцінка динаміки ультраструктурних змін та ранніх процесів апоптоза в тканинах нирок при експериментальному моделюванні гострого пієлонефриту (ГП) та супутнього цукрового діабету (ЦД) І та ІІ типів при проведенні комплексної медикаментозної корекції. Робота виконана на 300 дорослих щурах лінії Вістар, розподілених на 6 груп. Фрагменти нирок тварин вивчали і фотографували в електронному мікроскопі ПЕМ-100-01. У нирках тварин групи, де використовували традиційну медикаментозну корекцію після співдружнього моделювання пієлонефриту і діабету I типу виявлено, що ультраструктура клубочка більш збережена, однак частина капілярів клубочка залишається деформованою зі звуженим просвітом, є ознаки недостатнього відновлення функціонування клубочкової капілярної сітки. У групі тварин із використанням запропонованої комплексної медикаментозної корекції ниркова структура була збереженою, капіляри клубочкової сітки із незміненою архітектонікою. Встановлено, що традиційна медикаментозна корекція недостатньо сприяла відновленню пошкоджених ультраструктур тканин нирки. Після проведення запропонованої нами комплексної медикаментозної корекції в умовах співдружнього моделювання ГП і ЦД II типу ультраструктура тканин нирки за фоомою і структурою наближалась до такої контрольних тварин, проявились ознаки компенсаторно-відновного процесу: більиість подоцитів були гіперплазовані й гіпертрофовані. Подоцити зовнішнього листка знаходились в активній фразі діяльності, про що свідчило підвищення скорочувальної функції $i$, можливо, вивільнення сечі із порожнини до просвіту проксимальних канальців. Структура канальців та інтерстиційної тканини близька до структури групи контрольних тварин, лише в цитоплазмі подоцитів проксимальних канальців відмічений підвищений вміст лізосом. Ультраструктура клубочків нормалізовувалась; збільшувалась кількість гіпертрофрічних подоцитів внутрішнього листка з ознаками посиленого білкового синтезу. Зміни в структурах коркової та мозкової речовини аналогічні за винятком стану цитотрабекул, де їх розміри 
зменшувались в мозковій речовині і з'являлись ознаки деформації плазмолеми. При експериментальному моделюванні ГП $i$ ЦД I та II типів встановлені виражені ультраструктурні зміни в тканинах нирки, а прояви ранніх процесів апоптоза суттєво обмежені. Застосування комплексної медикаментозної корекції, запропонованої нами, стимулює розвиток репаративних процесів нирки та помірно активує апоптоз. Додавання до комплексу лікування препаратів багатовекторної дії (Армадіна та Нуклекса) інтенсифрікує компенсаторно-відновлювальні зміни у нирках та апоптоз, що сприяє елімінації 3 ниркових мікроструктур надлишка пошкоджених клітин та агресивних ефекторів запалення.

Ключові слова: нирки, ультраструктура, гостре запалення, гіпертрофія, медикаментозна корекція, апоптоз, моделювання.

\section{ВОЗМОЖНОСТИ ЛЕЧЕБНОГО ВОЗДЕЙСТВИЯ НА ДИНАМИКУ ПРОЦЕССОВ АПОПТОЗА В ТКАНИ ПОЧЕК ПРИ ОСТРОМ ПИЕЛОНЕФРИТЕ И СОПУТСТВУЮЩЕМ САХАРНОМ ДИАБЕТЕ В ЭКСПЕРИМЕНТЕ}

Борисов С.А. Костев Ф.И. Борисов А.В. Молчанюк Н.И.

Запрограммированая клеточная гибель в условиях инфекционно-воспалительного процесса играет биологически исключительно положительную роль в элиминации клеток. Острый воспалительный процесс - это явление, способное к надмерному сосредоточению агрессивных эффректоров воспаления. Целью работы стала оценка динамики ультраструктурных изменений и ранних признаков апоптоза в тканях почек при экспериментальном моделировании острого пиелонефрита (ОП) и сопутствующего сахарного диабета (СД) I и II типа при проведении комплексной медикаментозной коррекции. Работа выполнена на 300 взрослых крысах линии Вистар, разделенных на 6 групп. Фрагменты почек изучали и фотографировали в электронном микроскопе ПЕМ-100-01. В почках животных группы, где использовали традиционную медикаментозную коррекцию после содружественного моделирования пиелонефрита и диабета I типа установлено, что ультраструктура клубочка более сохраненная, однако часть капилляров клубочка оставалась деформированной с суженным просветом, есть признаки недостаточного восстановления функционирования клубочковой капиллярной сети. В группе животных с использованием предложенной комплексной медикаментозной коррекцией почечная структура була сохранена, капилляры клубочковой сети с неизмененной архитектоникой. Установлено, что традиционная медикаментозная коррекция недостаточно способствовала восстановлению поврежденных ультраструктур тканей почки. После проведения предложенной нами комплексной медикаментозной коррекции после содружественного моделирования ОП з СД II типа ультраструктура ткани почки по фрорме и структуре приближалась к таковой контрольных животных, проявились признаки компенсаторно-восстановительного процесса: большинство подоцитов были гиперплазированы и гипертрофированы. Подоциты наружного листка находились в активной фазе деяльности, про что свидетельствовало повышение сократительной функции и, возможно, высвобождение мочи из полости в просвет проксимальных канальцев. Структура канальцев и интерстициальной ткани близка к структуре группы контрольных животных, только в цитоплазме подоцитов проксимальных канальцев отмечено повышенное содержание лизосом. Ультраструктура клубочков нормализовывалась; увеличивалось количество гипертрофических подоцитов внутреннего листка с признаками усиленного белкового синтеза. Изменения в структурах коркового и мозгового вещества аналогичные за исключением состояния цитотрабекул, где их размеры уменьшались в мозговом веществе и появлялись признаки деформации плазмолеммы. При экспериментальном моделировании ОП и СД I и II типов установлены выраженные ультраструктурные изменения в тканях почки, а проявления ранних процессов апоптоза существенно ограничены. Применение комплексной медикаментозной коррекции, предложенной нами, стимулирует развитие репаративных процессов почки и умеренно активирует апоптоз. Добавление в комплекс лечения препаратов многовекторного действия (Армадина и Нуклекса) интенсифицирует компенсаторновосстановительные изменения в почках и апоптоз, что способствует элиминации из почечных микроструктур избытка поврежденных клеток и агрессивных эффректоров воспаления.

Ключевые слова: почки, ультраструктура, острое воспаление, гипертрофия, медикаментозная коррекция, апоптоз, моделирования. 